\title{
AGE-APPROPRIATENESS OF THE SCIENTIFIC VOCABULARY FOR BEGINNING READERS
}

Mare Müürsepp

Tallinn University, Tallinn, Estonia

E-mail: mare.muursepp@tlu.ee

\begin{abstract}
The study concerning an experimental learning material was carried out in the primary school. A specific feature of the innovative material is topic based on notions related to physics. Seven years old pupils' pre-knowledge of scientific notions have been analysed in the current study. A sample of the vocabulary suggested by the physicists was tested with different groups of respondents: pupils of the first grade, pupils additionally involved in extracurricular activities in the club "Friend of Science" and the students of a teacher training department. The notions selected by the physicists denote the phenomena of energy, space science, atomic and digital study area that up till now were not included in the actual primary school curriculum. As a result of this study, the fact has to be reported that the pupils - not having had any previous lessons on these themes - have given $72 \%$ right answers altogether, but the pupils involved in the special club, know nearly all presented notions. There are conclusions drawn from the current study for compiling of texts for beginning reader and for introducing the scientific themes in primary school lessons.
\end{abstract}

Key words: beginning reading, primary education, reading material, vocabulary, zone of proximal development.

\section{Introduction}

Current research is related to a very practical attempt of a group of young physicists, who would try to develop a textbook for the pupils of the first year of the primary school (7 years old in Estonian school). The group is internationally recognized, even repeatedly, as a finalist of the European Commission Descartes' Communication Prize in 2006 for the activity of the Science Bus called Big Dipper (Descartes 2007, 14) and the team of the best educational TV show called Rakett 69 (Rocket 69, Eurovision TV Summit 2012, 7). Also the young researchers are granted by the Estonian Physical Society for their popularizing activity (Estonian Academy of Science Yearbook 2012, 160).

According to their experience with children's audience the work group of physicists began to compile the reading materials for beginning reading. The vocabulary presented by them was tested by the experts of the primary school didactic in the current study, to analyse the appropriateness of the material for the pupils in the first school year.

\section{Problem of Research}

To justify the research problem mainly two discourses have to be spotlighted: reading studies and promotion of science for children. From one side reading research points out, that pupils need texts motivating for them. Reading material proposed in the school has to be relevant by its content and various by its sort and style (Bettelheim 1982, Hiebert \& Martin 2003, OECD 2010, Puksand \& Kerge 2011, Uusen \& Müürsepp 2012, Vaik-Luga 2013). From other side growing demand by society to empower the education in science is remarkable already 
Mare MÜÜRSEPP. Age-appropriateness of the Scientific Vocabulary for Beginning Readers

\section{PROBLEMS \\ OF EDUCATION \\ IN THE $21^{\text {st }}$ CENTURY \\ Volume 57,2013 \\ 80}

during decades. There are strategies worked out to motivate different groups like teachers, researchers and other agents to develop their teaching activities and educational environment to raise the level of education and research. All these strategies influence curriculum development to look for new opportunities to intensify learning process. (Knowledge-based Estonia 20072013, Sustainable Estonia 21)

Although the results of international studies concerning Estonian pupils' academic skills in science are relatively high, leaders of educational system worry about the fact, that only a small number of the pupils had expressed their interest to solve the problems in science (Henno 2008). The topic of the textbooks may motivate to deal with the issues of science.

However, comparing Estonian textbooks with teaching materials of other countries, Lätt (2010) has detected, that many themes concerning physics and specially space are ignored in Estonian materials, although these are treated in other countries. Heli Lätt is also experienced as a supervisor of children's Space Club, thus she proposed many concrete notions and sub-themes which would be introduced earlier than these are presented in contemporary school practice, while the issues related to space flights, space observation and research are very motivating for pupils already beginning from their young age. (Lätt 2010)

Innovation in contemporary science teaching for the first school stage has to be characterized by two features today: tendency to use more experimental activities in school (Koppel, Reedik \& Voronina 2010, Pärtel 2010) and a growing network of the institutions proposing extracurricular activities related to science and technology, like the movement of SmartLabs, engaging younger pupils in 24 laboratories in school year 2013/2014 with activities like 3D modelling, robotics and other fields of technology. (About... 2013) There are many workers outside of the general school system, coming to the idea to provoke the children's interest to deal with science.

Recent study by the Praxis Centre for Policy Studies evaluating the outputs and outcomes of various activities for popularizing science and technology in Estonia provided recommendation to offer more activities for younger pupils. While music, dance, sports and some other very popular sectors engage gifted children already very early, then the actions popularizing science adressed to the end of basic school cannot find so much interested followers, because the pupils already have preferred other fields of activities. (Haaristo, Kirss, Nestor \& Mikko 2013, 6) Hence the aim of the physicists to compile a textbook for beginning readers is reasoned by their recognition, that the notions and phenomena concerning physics are interesting for children already long before such themes are introduced in curriculum and today textbooks.

Their assumption is supported by the results of the newest study of the textbooks for the first school year (Vaik-Luga 2013). Analysing teacher's evaluations to the reading material in primers used in school in 2012, the researcher points out teachers' opinion, that the texts in primers do not widen pupils' horizon, in other words - these are not very interesting for the pupils of the first grade. Mostly the indicators by the teachers' evaluation to the values of the texts are only on medium level. Thus there should be some opportunities to include more enticing and enriching texts in primers.

There is an engrained tradition concerning the primers and textbooks for the first school level to prefer the texts like short fairy tales, animal tales and descriptive texts about child' everyday activities (Vaik-Luga, 2013). However the pupils of the first grade (they are seven years old in Estonian school) are often experienced already in the computer world, they have travelled a lot, and their curiosity demands more input than the traditional primers' texts would introduce. Already Bettelheim confirmed in his treatment of the problems of beginning reading, that the shortage of the reading motivation may be reasoned by meaningless texts in materials for the first steps in reading (Bettelheim 1982).

Introducing the notions used in science and technology, a question arises about the genre of text more suitable to use in the materials for the beginning reader. There is the opposition between the narrative and exploratory types of text under discussion concerning the beginning readers abilities. Although a number of scholars have argued the predominance of narrative 
text in primary classroom, there are studies which confirm, that the children in primary school age are able to learn also about and from expository text. (Morrow \& Gambrell 2003, 354) The results of PISA and other large comparative studies bring out that namely these young readers who read a wide variety of material perform particularly well in reading (OECD 2010, 12; Uusen \& Müürsepp 2012).

Speaking about the beginning readers, pupils of the first grade are considered as the addressee of the texts in the current project, because it is the beginning of the formal compulsory education, where state institutions are obliged to provide necessary learning materials. Of course reading skills develop from early childhood and the children coming to school at age seven years old are on different levels of their development of reading skills. By Vilimaa's recent study (2013) mostly the pupils in the first grade use the reading by syntagmas or spelling as their leading techniques. Therefore they need texts specially compiled for their level of reading skills.

According to Hiebert and Martin $(2003,362)$ there are three types of text for beginning reader identified. These are high frequency texts, phonics texts and literature-based texts. In the texts described as high-frequency texts certain words are over-presented (for example some pronouns). Phonics texts support word recognition through a preponderance of decodable vocabulary. Concept of literature-based texts emphasizes the meaningfulness of the entire text, one form of which are "predictable" texts which repeat phrases or sentences. Also Hiebert confirms that any of texts can embody any of these supports to varying degrees (Hiebert \& Martin 2003, 362).

Consequently the texts using the notions related to physics may be compiled using the features mentioned by Hiebert and Martin - high frequency of certain words, sound image based on the use of certain phonics and other literary ways to engage young reader. A book by semiotic Umberto Eco "The Bomb and the General" can be mentioned as a good example of the text using scientific notions in simple literary form (Eco 1989). Of course, a question may be asked about the non-fiction books already published for children: is it important to generate one more? Unfortunately, these series of picture books about space, light, power and other physical phenomena are translated from other languages, and the text there is often deplored by the critics of children's literature and reading teachers, because the translated text is not clear and fluent as necessary for the beginning reader (Kumberg 2001).

Thus according to the studies about reading habits and beginning reading, the initiative of the young physicists deserves support and interest by specialists of the primary education, especially in the light of the contemporary demand of the society to popularize the science to younger pupils. New reading material may be helpful to enhance pupils' reading motivation as well to encourage their interest to science.

\section{Research Focus}

Current research focuses on a question about age-appropriateness of the vocabulary, selected by the physicists for textbook of beginning reading. Suitability of the vocabulary will be analysed in the context of the theory of the zone of proximal development. The study introduced here is significantly supported by Lev Vygotsky's concept of the zone of proximal development (ZPD). The notion ZPD has been explained as "the distance between the actual developmental level as determined by independent problem solving and the level of potential development as determined through problem solving under adult guidance, or in collaboration with more capable peers" (Vygotsky 2005, 11). Thus, Vygotsky has viewed interaction with peers as an effective way of developing skills and strategies. Both Vygotsky's and Piaget's and other classics' theories of social factor in learning are implied in today primary education practice and research (Blatchford 2005; Howe \& Tolmie 2003, Wilkinson \& Silliman 2000), and group work is an important issue of many innovative approaches in our primary education.

While the current study was caused by the idea to compile a textbook for beginning 
Mare MÜÜRSEPP. Age-appropriateness of the Scientific Vocabulary for Beginning Readers

\begin{abstract}
PROBLEMS
OF EDUCATION

IN THE $21^{\text {st }}$ CENTURY

Volume 57,2013

82

reading, when supporting communication in collaborative activities is very essential, then the vocabulary intended to innovate the reading material was tested in group work. If the pupils would be able to find solutions in group work, then according to the ZPD theory this kind of activity tends to belong to pupils ZPD.

The main research purpose was to test, how the pupils in age 7 years would know the notions presented by the scientists for the experimental reading material.
\end{abstract}

\title{
Methodology of Research
}

\section{General Background of Research}

In principle the research question about the appropriateness of the words assumes an investigation of presence of these words in pupils' passive vocabulary. Are pupils in the first grade able - at least somewhat - to understand the notions presented them, although probably they do not actually use these?

Researchers of children's language point out a need to study children's vocabulary considering the concrete context where they live and to create a corresponding instrument for measuring, additionally using informal methods to describe and analyse children speech. Tests for assessment of passive vocabulary investigate connections between words and accordance between a word and an imagination (Karlep, 1998; Witt 1998, 279). Different tests, naturalistic observation, interviews with teachers and parents are necessary to use as mutually complementing methods. General principles of authentic assessment are followed in current research, to ensure a situation similar to pupils' everyday work in the lessons (Bagnato 2007).

According to the theory of the zone of proximal development the collaborative learning is an important factor to empower the learning process. For that reason the work in group was an idea of the empirical part in current study. Researchers were interested not in the individual performance of each pupil, but in the results the pupils demonstrate working in a group.

Recent studies of teachers opinions about the new primers demonstrate, that teacher's judgements are mostly compliant with academic researchers' results, concerning the qualities like readability and complexity of the text (Rand 2013, Vaik-Luga 2013). Hence teachers' standpoint was valued in the current study. Teachers were interviewed to have their comments to the group work in their classrooms. Also a group of primary school teacher students were asked to evaluate the appropriateness of the selected words, while today students have to be open to the innovative approach in teaching materials.

Additionally the analysis of documents was used as a method, to compare how much the word selection is presented in the syllabus and textbooks for the age group studied in the research.

\section{Sample of Research}

To treat the results in the light of the theory of ZPD, two different categories of pupils were asked to realize the task presented by the researchers. There were two classes of the first grade as presenters of normal school pupils, and a group of children, who additionally takes part in children's extracurricular activities concerning science - the pupils visiting the club "Friend of Science".

The children were at age 7-8 years, 52 pupils of the first grade and 20 pupils, who additionally visit their science activities. The pupils worked in the groups four members per group.

There were three teachers interviewed in the study, two of them are the teachers of the first grade and one is the supervisor of children's science club. As presenters of future school there were 36 students of the second course of teacher education department involved in the research. The students of the second year were selected because they have already certain experience at school, they have observed and analysed lessons and also many of them have their 
personal experience in working with children, but at the same time they have not studied the didactics yet, they do not know the demands and rules of teaching concerning the topic and methods, thus they are relatively free of the limits in their imagination.

\section{Instrument and Procedures}

A research instrument was a list with words and series of lists with pictures. The task given to the pupils was similar to the exercises and games they do in every lesson: match the picture and word. The words were given on a list, printed in big font. The pictures were on sheets separately each of them, with free place to write the notes there.

The words used in the study were: rocket, crystal, magnet, rainbow, space suit, oxygen, digital, diode, universe, energy, galaxy, atom, bit, byte, nano. Although some of the words presented in the research are only prefixes in our language (nano-, digi-/digital), these are used in spoken speech as nouns (digikas in the native language - a digital tool, digital camera, digital box etc), and their structure is relatively suitable for the beginning reader.

Some of the words signify very concrete things, but there are also words which meaning is more abstract; then there are the pictures with the objects, which denote some concrete cases of using the notion (like diode - LED lamp, bit - computer's microcircuit, oxygen - human respiratory system). The pupils were instructed to find a picture to each word on the list and to write the word to the picture. Additionally the pupils were encouraged to write their own comments to the pictures.

Similarly the novice teachers were asked to match the pictures and the words. Their task was also to note, what they think about the concrete notions in the context of the primary school teaching. Namely, they were asked to write the number of the grade, when each of given words may be appropriate to introduce in classroom.

Additionally the data were collected by observation of pupils' activity by the teacher of the same group of pupils. The teachers were asked to answer: How do they assess the appropriateness of the words presented for their pupils? How do they comment the work process - matching words and pictures in the group? How do they compare the research procedure with their usual lessons and pupils' activity with their everyday behaviour? Interviews were taped.

Comparative analysis of the word selection and topic in the parts of the National Curriculum, namely in the syllabi of science, technology and language was realized to see, which of the notions are expected to be treated in the first school stage.

\section{Data Analysis}

According to the activities in research procedure the data were analysed in different sections:
I. Pupils' answers
II. Teacher training department students' answers
III. Interviews with teachers
IV. Analysis of syllabi

I Pupils' answers were analysed ascertaining which words are matched correctly and which not, and what kind of explanations are given to the words and pictures. Summarizing all relevant answers given in group work the percentage of relevant answers was calculated.

II Teacher training department student teachers' answers about the appropriateness of the presented words were analysed by the grade mentioned in answers. Student teachers' proposals concerning the time to deal with the topic related to the presented notions was analysed and the minimum and the maximum age of pupils defined.

III audiotape interviews with teachers were analysed and text units coded, teachers' answers and comments were grouped by the subthemes according to the questions asked in interview. 
Mare MÜÜRSEPP. Age-appropriateness of the Scientific Vocabulary for Beginning Readers

\author{
PROBLEMS \\ OF EDUCATION \\ IN THE $21^{\text {st }}$ CENTURY \\ Volume 57,2013 \\ 84 \\ IV Results of comparative analysis of the word selection and syllabi of science, technol- \\ ogy and language brought out the notions presented in syllabi.
}

\title{
Results of Research
}

The results of the activities matching words and pictures are at first separately concerning the answers of the normal class and then in the group with additional extracurricular activity.

All together there were $72 \%$ of relevant answers in the first grade, thus mostly the groups have given a lot of right connections between the words and pictures signifying the notions related to physics. Words known for each group in the first grade were: rocket, crystal, magnet. Words known for more than half of the groups were: rainbow, space suit, oxygen, digital, universe, energy, galaxy. No relevant answers were given about 'nano'. Only some answers were proposed for 'atom', 'bit', 'byte', 'diode'.

The connections were given like 'oxygen' - human organism, lung; 'digital' - computer, the switchboard, electronics, connector; 'energy' - solar panel, windmill, wind generator, diode, atom, nano, also an original word was given by children - 'windrator' (obviously from 'wind' and 'generator'). The word 'atom' was not known very often, but the connections were with words

'galaxy' and 'universe' many times, while the schemes of the atom and the solar system seemed similar (teacher's comment), the words 'bit' and 'byte' were associated with 'computer scheme, diode, digital, energy, atom, galaxy, city plan, view from the air' - while the picture of the microcircuit reminds an aerial photo. The picture of the nanomaterial was the most unknown in the first grade, there were comments that it seems to be similar to the cells and corals.

The groups of pupils in the same age visiting their extracurricular activities in the club "Friend of Science" have given $93 \%$ of relevant answers. Consequently all these words, presented in the study are less or more known for them. Some single answers were not given to the words 'diode', 'atom', 'bit' and 'byte'. Even the picture-question about nanomaterial was simple for the children having some experiences in science.

Drawing together the results in both categories of pupils a conclusion may be derived, that the words less known by the pupils signify very small, invisible or abstract objects (atom, bit, byte) and these words are relatively new (diode, nano).

Students' as future teachers' opinions about the appropriateness of the presented notions are various. The notion solidly mentioned as necessary to treat in the first grade was 'rainbow'. 'Rocket', 'magnet', 'space suit', 'oxygen' are the words suitable to introduce during the first school stage (grades 1.-3, pupils age from seven to ten years). In many cases the students' rates to the age-appropriateness diverge essentially. There are the future teachers who think, that the words 'crystal', 'digital', 'universe', 'galaxy', 'atom' note the phenomena important to introduce already in the first grade or at least during the first school stage, at the same time there are their colleagues who would delay introduction to such phenomena to the end of the basic school (grades 8 or 9). Very generally students' decision about the age-appropriateness of the notions harmonizes with pupils' knowledge in the sense that the words which are less known for the children are noted as suitable to teach later, and the words known more by the children are suggested to teach during the first school stage. Students commented their answers mentioning that their opinion is influenced by their own school experience: they remember which themes have seemed complicated for themselves during their study in basic school.

Teachers both of the first grades and of the group of the club "Friend of Science" approved the attempt to innovate the reading material for children. They found the work in groups similar to their teaching process, confirming that the children are used to discuss and solve the problems in group work. All teachers who took part in the research admitted, that the children are very interested in a new knowledge, that they have used to follow the news in mass media, they catch new words and try to use them, and often the teachers have to recognize even children's superiority especially concerning new media and technology. "Probably children's 
knowledge is not very deep, but I am not able to comment or to correct pupils'sayings" - teachVolume 57, 2013 er's saying in interview. The teacher of the extracurricular club is in a better position, while her work is to organise the meetings with scientists and the visits to the scientific and industrial centres, where the experts in different fields share their knowledge with children.

Which of the notions used in the research, are presented in the syllabi of different subjects for the younger school level? There is only the notion 'magnet' mentioned in the syllabi for the first school stage (grades $1-3$ ).

To demonstrate knowledge of the words by the pupils of the first grade and the presence of the words in the official syllabi the figure 1 is compiled.

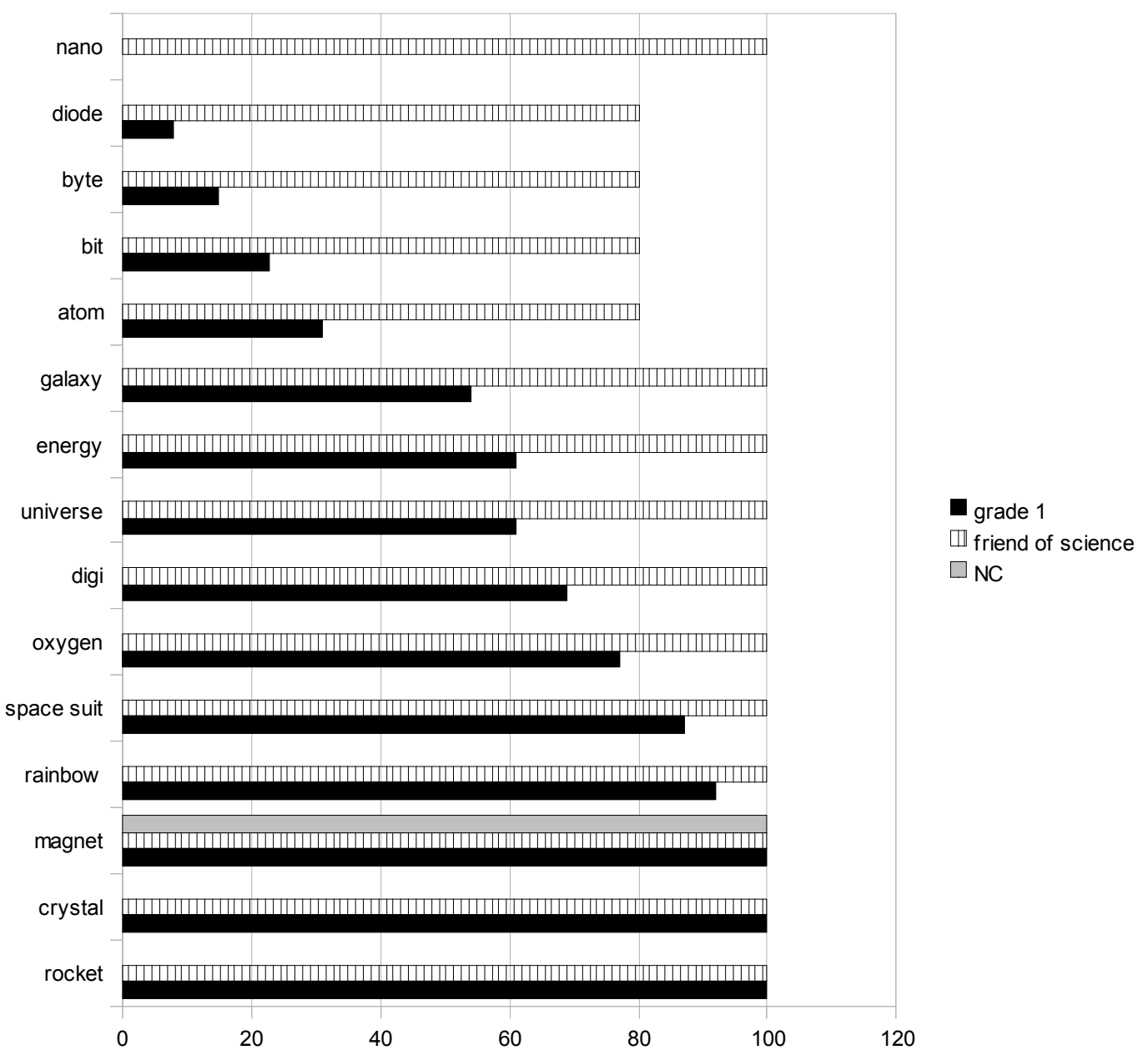

Figure 1: Percent of the right answers by the pupils of the first grade and by the pupils in the club "Friend of Science"; presentation of the notions in National Curriculum in the section of the first stage.

\section{Discussion}

While the research focused on the question of the age-appropriateness of the vocabulary proposed by the physicists for the material of the beginning reading, the answers has to be given, that these words are relatively known for the pupils in the first grade. Working together in the groups the pupils were able to match the words and the pictures, and specially the pupils visiting extracurricular activities related to science have demonstrated a good knowledge of 
PROBLEMS

OF EDUCATION

IN THE $21^{\text {st }}$ CENTURY

Volume 57,2013

86

confirm, that the words related to physics may serve the goal to compile an innovative textbook, which topic is motivating for the pupils of the first grade. Proposed notions constitute meaningful words, which by Hiebert \& Martin (2003) are notably significant in the text for beginning reader. Thereby Hiebert \& Martin (ibid) pointed out collective essence of reading training.

How to treat the experience obtained in current research in wider context? The fields of reading teaching and science promotion were prioritized as the most significant to clarify the questions of the beginning reading material using the scientific notions. However the issues of the curriculum and the general justification of the topic of the primary education rise to the forefront.

As mentioned above, in her study Lätt (2010) suggested to introduce the space phenomena for the first school stage first and foremost in extracurricular activities. Relevance of extracurricular activities became evident also in the current study. The pupils visiting scientists knew more words related to physics, they seemed to be very well prepared to read the texts using vocabulary proposed in the research.

At the same time a pupils' chance to be involved in extracurricular activities depends on parents and teachers enterprise. How to reach all children into activities which are more interesting than usual school lessons? Obviously the key person to enrich pupils' experience might be the primary school teacher, who has wide horizon him/herself and who would be ready to learn new things him/herself. The students of teacher education department and the teachers interviewed in the study admitted, that they have to reappraise their own school experience related to science, because today children come from childhood environment which is very different from previous generation's settings. Above-mentioned recent study of popularization of science (Haaristo 2013,6) highlighted that no teachers' skills and knowledge nor existent textbooks do not support innovative learning sufficiently. Also there was a reproof that generally in society the scientific worldview is not accepted enough. Therefore, implementation of innovative reading material for beginning reading demands more than compiling a book. Obviously there has to be an assisting material for the teacher and maybe also for the parents, or a website to open the issues for family reading and educational activities.

Another issue inviting to discuss, is the presence of scientific notions in syllabi of primary school. The leaders of the science working group at National Curriculum have expressed a doubt, that young pupils are not able to understand many phenomena in their deepest essence, and if the children would meet a concept too early, they would acquire a wrong and incomplete meaning of the notion (Koppel 2010; Pärtel 2010). Critically thinking this position seems to be neither very conscious nor consistent, while for example the Sun is a very frequent motif in children's text, but hardly a child has to think that it is "a sphere of plasma held together by its own gravity". As theorists of learning and child development explain, the concepts are ideas only in our mind, they are made up of examples, and new facts and examples influence the concept's forming (Parker 2005, 324). Smith (2008, 428), summarizing the studies about child knowledge and memory, points out that if the children have gained some information in certain field, then it is more simple for them to code the units of new information in the same field.

How to legitimate the selection of topic, including reading material for the first school year, is a question related to many different disciplines related to the research of children's thinking, language, teaching history, cultural tradition and other subjects. As strange as it may seem, it is not very simple to justify in academic concepts, what should be and what not should be the topic and the characteristics of the texts for beginning reading, as Hiebert \& Martin revealed in their overview in a respectable handbook $(2003,361-362)$ that there is a limited number of studies on the effects of texts on children's reading acquisition. Els Oksaar, the first president of the International Association for the Study of Child Language confirmed (Oksaar 1987), that the child coming to school would use a second language - written language. However the study of children's language concentrates on the earlier phases of pre-school development. Smith in his "Understanding Children's Development" recognised that there is lack of 
consensus between theorists about development of children's phonological, syntactic, semantic and pragmatic language. (Smith, Cowie \& Blades 2008, 371). Looking on the history of the textbook development a cultural tradition seems to be the strongest influence in the selection of the text for beginning reading (Müürsepp 1998, Vaik-Luga 2013). From another side, today the research of the textbooks is losing its academic weight, because it is influenced by the publishing industry, as Hiebert warns (Hiebert \& Martin 2003, 372). Obviously the compiling of a contemporary motivating and developing textbook for the beginning reader remains a mission solved in interaction with the target group.

Contemporary reading teaching ideology, pointing out the constructivist approach and concepts of emergent literacy and whole language develops the ideas of Vygotsky's social constructivist theories in many aspects. The idea to motivate the pupils to read and to guess the words related to science and technology and to use these words in simple texts compiled by certain rules for beginning reading seems to be in accordance with up-to-date reading teaching theories. (Morrow 2012; Wilkinson \& Silliman 2000).

The issues of the elementary textbook have to be situated also in more general framework of primary education. Alexander $(2001,146)$ has distinguished different approaches to primary education - elementary, preparatory, developmental, progressive, behavioural-mechanistic, classical humanist and others. Surely acceptance of certain reading material depends on the attitude of the respondent - or teachers, or parents, or publishers or else - towards the aims and functions of the primary stage. The presenters of the project introduced here believe that primary education has to open a wide horizon of knowledge of nature and human progress and to excite an interest to know more and more.

\section{Conclusions}

Current research concentrated on the question about the vocabulary selected by the physicists for a textbook of beginning reading. Age-appropriateness of selected words was tested in the first grade. Suitability of the vocabulary was analysed in the context of the theory of the zone of the proximal development. The results of the study demonstrate that the notions related to physics are relatively known for the pupils of the first grade, so that the activity based on this vocabulary may be defined as belonging to the zone of proximal development. The next step of the work has to be compiling of the texts using the notions and the study of children's reception.

The results of current research are important both for textbook compilers, encouraging them to use more contemporary vocabulary, known by the children from their everyday life, and also for teacher education to prepare the novice teachers to cope in rapidly changing educational environment.

\section{Acknowledgements}

Member of the team of physicists PhD Heli Lukner has to be acknowledged for her enterprise and initiative to inspire the study of the materials for beginning reading.

\section{References}

About SmartLabs (Nutilabor) (2013). http://www.nutilabor.ee/en/

Alexander, R. (2001). Culture \& Education. International Comparisons in Primary Education. Blackwell Publishing.

Bagnato, S. J. (2007). Authentic Assessment for Early Childhood Intervention. Best Practices. New York, London: The Guildford Press.

Bettelheim, B. (1982). Kinder brauchen Bücher. Lesen lernen durch Faszination. Stuttgart.

Blatchford, P. J. (2005). Improving the Effectiveness of Pupil Groups in Classrooms: ESRC End of Award Report, L139251046. Swindon: ESRC. 
Mare MÜÜRSEPP. Age-appropriateness of the Scientific Vocabulary for Beginning Readers

PROBLEMS

OF EDUCATION

IN THE $21^{\text {st }}$ CENTURY Volume 57,2013

88

Cronbach, L. J., \& Meehl, P. E. (1955). Construct validity in psychological tests. Psychological Bulletin, 52, 281-302. doi: 10.1037/h0040957.

Descartes Communication Prize. Excellence in Science Communication. (2007). Brüssel: European Commission. http://ec.europa.eu/research/science-wards/pdf/descartes_communication_2006_en.pdf

Eco, U. (1989). The Bomb and the General. Chicago: Harcourt Children's Books.

Estonian Academy of Science Yearbook XVIII (45) (2012). Tallinn: Estonian Academy of Science.

Eurovision TV Summit (2012). Special Focus Day on Nordic Media. Copenhagen 24 - 27 April. Programme. http://www.eurovisiontvsummit.com/eurovision-2012/wp- content/uploads/2012/01/SpecialFocusDay_FR.pdf

Haaristo, H. S., Kirss, L., Nestor, M., \& Mikko, E. (2013). Teadust ja tehnoloogiat populariseerivad tegevused Eestis. Tallinn: Poliitikauuringute Keskus Praxis.

Henno, I. (2008). Mida mõõtis PISA 2006? Õpetajate Leht, 25. jaanuar.

Hiebert, E. H., \& Martin, L. A. (2003). The Texts of Beginning Reading Instruction. In Neuman, S. B. \& Dickinson, D. K. Handbook of Early Literacy Research. New York, London: The Guilford Press. 361-376.

Howe, C., \& Tolmie, A. (2003). Group work in primary school science: Discussion, consensus and guidance from experts. International Journal of Educational Research, 39 (1-2), 51-72.

Karlep, K. (1998). Psühholingvistika ja emakeeleõpetus. Tartu: Tartu Ülikooli kirjastus.

Karlep, K. (2003). Emakeele abiõpe II. Kõnearendus. Tartu: Tartu Ülikool.

Koppel, L., Reedik, M., Voronina, A. (2010). I kooliaste loodusõpetus 1.-3. klassile. Loodusained: põhikooli valdkonnaraamat. Tallinn: Riiklik Eksamija Kvalifikatsioonikeskus.

Knowledge-based Estonia. (2007). Estonian Research and Development and Innovation Strategy 2007 2013. Tartu: Estonian Ministry of Education and Research.

Kumberg, K. (2000). Tõlkekirjandus näitab keelt. Nukits. Tallinn: Eesti Lastekirjanduse Teabekeskus, 21-23.

Lätt, H. (2010). Kosmos kui atraktiivne teema õpilaste õpimotivatsiooni tõstjana loodusteadustes. Tartu Ülikool: Loodusja tehnoloogiateaduskond magistritöö.

Morrow, L. M. (2012). Literacy Development in the Early Years: Helping children Read and Write. Boston: Pearson.

Morrow, L. M., \& Gambrell, L. B. (2003). Literature-Based Instruction in the Early Years. In Neuman, S. B. \& Dickinson, D. K. Handbook of Early Literacy Research. New York, London: The Guilford Press. 348-360.

Müürsepp, M. (1998). Laps on hakanud lugema. Tallinn: REKK.

OECD (2010). PISA 2009 Results: Executive Summary.

Oksaar, E. (1987). Spracherwerb im Vorschulalter. Einführung in die Pädolinguistik. Zweite Auflage. Stuttgart-Berlin-Köln-Mainz: Kohlhammer.

Parker, W. (2005). Social Studies in Elementary Education. The 12th Edition. Pearson College Division.

Puksand, H., Kerge, K. (2011) Õpiteksti analüüs kirjaoskuse omandamise kontekstis. Emakeele Seltsi aastaraamat, 57, 162-217. http://www.kirj.ee/public/ESA/2011/esa_57-2011-162-217.pdf

Pärtel, E. (2010). Probleemide lahendamisel põhinev õpe loodusõpetuses. Loodusained: põhikooli valdkonnaraamat. Tallinn: Riiklik Eksamija Kvalifikatsioonikeskus.

Rand, M. (2013). Aabitsate keerukus: keeleline analüüs ja õpetajate hinnangud. Tartu Ülikool. Sotsiaalja haridusteaduskond. Magistritöö.

Smith, P. K., Cowie, H., \& Blades, M. (2008). Lapse arengu mõistmine. /Understanding Children's Development. 4th Edition. Tallinn: TLÜ kirjastus; Blackwell Publishing.

Sustainable Estonia 21 (2005). Estonian National Strategy on Sustainable Development. Tallinn: Estonian Ministry of Environment.

Uusen, A., \& Müürsepp, M. (2012). Gender differences in reading habits among boys and girls of basic school in Estonia. In Procedia - Social and Behavioral Sciences. International Conference on Education and Educational Psychology ICEEPSY 2012, 69, 1795-1804.

Vaik-Luga, R. (2013). Opetajate hinnangud aabitsatele laste õpioskuste toetajana. Tartu Ülikool. Sotsiaalja haridusteaduskond. Bakalaureusetöö.

Vilimaa, P. (2013). Aabits lugemisoskuse kujundamise vahendina. Tartu Ülikool. Sotsiaalja haridusteaduskond. Bakalaureusetöö.

Vygotsky, L. (2005). Mõshlenije i rech. Psihologija razvitija cheloveka (Мыцление и речь. Из книги: Выготский Л.С. Психология развития человека. Москва: Изд-во Смысл; Эксмо. http://yanko.lib.ru/books/psycho/vugotskiy-psc_razv_chel-7-myshlenie_i_rech.pdf. 
Wilkinson,L.C.,\&Silliman,E.R.(2000).Classroomlanguageandliteracylearning.ReadingOnline.Electronic Journal of International Reading Association. http://www.readingonline.org/articles/art index. asp?HREF=/articles/handbook/wilkinson/index.html

Witt, J. C. (1998). Assessment of At-risk and Special Needs Children. McGraw Hill Higher Education.

Advised by Tero Autio, Tallinn University, Tallinn, Estonia

Received: September 25, 2013

Accepted: December 13, 2013

Mare Müürsepp 